\title{
Persistence and Migration of Alkylphenol Ethoxylate Degradation Products Associated with Land-applied Biosolids
}

\author{
Mark J. La Guardia *a, Robert C. Hale a , Ellen Harvey ${ }^{\text {a }}$, \\ Elizabeth O. Bush ${ }^{a}$ and Serena Ciparis ${ }^{b}$ \\ ${ }^{a}$ Department of Environmental \& Aquatic Animal Health \\ Virginia Institute of Marine Science \\ The College of William \& Mary, Gloucester Point, Virginia 23062 \\ ${ }^{\mathrm{b}}$ Department of Entomology \\ Virginia Polytechnic Institute and State University \\ Blacksburg, Virginia 24061 \\ markl@vims.edu
}

\begin{abstract}
Nonylphenol (NPs) and nonylphenol ethoxylates (NPEOs) enter the environment during the course of land-application of sewage sludge (biosolids). These xenoestrogens have been previously reported in biosolids at concentrations as high as parts per thousand, $\mathrm{g} / \mathrm{kg}$ (dry weight). Here we examine their residence time and potential for migration during runoff events from pasturelands that received biosolids (anaerobic and aerobic/lime stabilized). Biosolid aggregates $(>0.5 \mathrm{~cm})$ were randomly collected for analysis from these fields at 50 and 175 days after application. Concentrations from each set were compared to the original material. Minimal mineralization was observed 50 days after application, but was substantially greater at 175 days for NPs and NPEOs. Surface runoff created by means of applying artificial rainfall to the biosolids treated and control pasture-plots were compared. Greater levels $(\mathrm{P}<0.05)$ of NPs and NPEOs were observed for the treated plots (range 1.69 to $5.35 \mu \mathrm{g} / \mathrm{L})$. A stronger correlation $\left(\mathrm{R}^{2}\right.$ $=0.562$ ) between NP concentrations and PtOC (particle organic carbon) was also observed compared to DOC (dissolved organic carbon) $\left(\mathrm{R}^{2}=0.125\right)$ and TOC (total organic carbon) $\left(\mathrm{R}^{2}=0.252\right)$, indicating that NPs were more associated with runoff solids. Although not conclusive, during the first 50-days after application grazing animals have the greatest potential to be exposed to NPs and NPEOs with burdens continuing at a minimum up to six months thereafter. (U.S. regulations restrict grazing up to 30 days after application.) It also appears that these xenoestrogens have the potential to migrate with runoff from biosolid-applied fields during rainfall events.
\end{abstract}

\section{KEYWORDS}

biosolids, endocrine disruptors, nonylphenol, surfactants, runoff 


\section{INTRODUCTION}

Application to agricultural lands is a cost-effective alternative for the disposal of sewage sludge (biosolids). Approximately $60 \%$ of the 5.6 million tons of sewage sludge generated in the U.S. (2002) is land-applied (National Research Council, 2002). Associated benefits include recycling nutrients to lands and crops; increasing organic soil matter and improving of soil properties such as porosity and water retention. However, concerns related to land-application of biosolids have included: accelerated eutrophication of surface waters from release of excess phosphorus, ground water contamination by nitrate leaching, health risks from the transfer of pathogenic organisms to humans or animals, uptake of trace elements (heavy metals) by plants and potential exposure to toxic organic chemicals. Some of these concerns are being addressed with additional management practices. However, biosolids have recently been reported to contain pharmaceuticals, steroids and hormones, flame-retardants and additional metals (U.S. Environmental Protection Agency, 2009), which were not considered under U.S. EPA Rule 503, original risk assessment (U.S. EPA, 1993).

NPEOs are commonly used as surfactants in detergents, paints, pesticides, textiles, and personal care products. NPEOs have also been shown to degrade to more toxic and lipophilic compounds, NPs, nonylphenol monoethoxylates (NP1EOs) and nonylphenol diethoxylates (NP2EOs) in wastewater treatments plants (WWTPs), primarily residing in sewage sludge during the treatment process (Ahel et al., 1994). Environmental contamination by NPEOs degradation products has been reported in many areas of the world. Sediment cores taken from areas influenced by WWTPs (including Tokyo Bay, Japan and the Strait of Georgia, British Columbia, Canada) have shown increasing levels of NPs since the mid 1960s (Yamashita et al., 2000 and Shang et al., 1999). Sediments sampled near a WWTP that had ceased treatment operations 20 -years prior contained 54 $\mathrm{mg} / \mathrm{kg}$ of NPs (Hale et al., 2000), indicating modest degradation in anaerobic sediments. Leachate from a Swedish municipal landfill, which received WWTP sludge, was previously shown to contain NPs at $107 \mu \mathrm{g} / \mathrm{L}$ (Öman and Hynning, 1993). Groundwater contamination by NPs and NPEOs has also been reported in Switzerland, Israel and the U.S. (Tamage, 1994, Zoller and Hashan, 2000 and Rudel et al., 1998). NP1EOs and NP2EOs have been detected in U.S. drinking water at up to $34 \mathrm{ng} / \mathrm{L}$ (Clark et al., 1992 and Kuch and Ballschmiter, 2001). NPs and NPEOs have also been detected up to $\mathrm{g} / \mathrm{kg}$, dry weight (d.w.) in biosolids (La Guardia et al., 2001 and Kinney et al., 2006). Rapid 4NP [ring-U- $\left.{ }^{14} \mathrm{C}\right]$ mineralization was postulated using well-aerated arable soils containing sewage sludge under laboratory conditions (Topp and Starratt, 2000), but within 2-cm sludge aggregates containing anaerobic centers, NPs were detected and extrapolated to persist for more than 1 year (Hesselsoe et al., 2001). A Canadian study indicated that $60 \%$ of the original NPs remained in the soil 60 days after application, but decreased to non-detectable levels 90 days after application (Environmental Canada, 1998). A Danish study also suggests that soil concentrations of NPs, NP1EOs and NP2EOs remained constant during a 28-day testing period (Danish Environmental Protection Agency, 1998). 
Concerns have been raised about the potential estrogenic effects of NPs. Those with the hydroxyl group in the para position have been shown to displace $17 \beta$-estradiol from the estrogen receptor (Soto et al., 1995 and Routledge and Sumpter, 1997). Recently altered testicular development was observed in the fetuses of pregnant sheep grazing on appliedbiosolid lands. This was attributed to exposure to estrogens and xenoestrogens present in biosolids (Paul et al., 2005). Nonylphenols ethoxyolates (NPEOs) and the related degradates nonylphenols (NPs) have been shown to disrupt the endocrine system in aquatic organisms (Gray and Matcalfe, 1997). NPs and NP2EOs have been reported to induce vitellogenin production in male trout (Oncorhynchus Mykiss)) and in minnows (Pimephales promelas) at low $\mu \mathrm{g} / \mathrm{L}$ concentrations (Jobling et al., 1996 and Harries et al., 2000). Expression of intersex (testis-ova) in medaka (Oryzias latipes) was observed following exposure to NPs at $50 \mu \mathrm{g} / \mathrm{L}$ (Gray and Matcalfe, 1997). Agricultural headwater streams were shown to contain elevated levels of NPs $(\sim 8 \mu \mathrm{g} / \mathrm{L})$ during storm events; the majority of the storm water toxicity was attributed to NPs as determined by toxicity identification evaluation (TIE) of Daphnia magna (Thomas et al., 2001). The source of NPs was believed to be associated with pesticide formulations (pesticide formulations can contain up to $97 \%$ NPEOs), but other sources could not be ruled out. Canadian researchers however, did link regional declines in Atlantic salmon to forest application of pesticides containing NPs (Fairchild et al., 1999). It was also reported that NPEOs were shown to have the potential to disrupt breeding habitats of amphibians. These habitats are often shallow, lentic or ephemeral water bodies, which can be heavily associated with agricultural runoff. Narcosis was reported in six species of tadpoles when exposed to NPEOs (48h EC50 ranged between $1.1 \mathrm{mg} / \mathrm{L}$ (mild narcosis) and 25.4 $\mathrm{mg} / \mathrm{L}$ (full narcosis)) (Mann and Bidwell, 2001).

Canada has placed NPs and their ethoxylates on their second Priority Substances List (PSL2), proposing that they be classified as "toxic", as defined under Section 64 of Canadian Environmental Protection Act (CEPA). NPs (CAS\# 25154-52-3 and 84852-153) are listed on The U.S. Toxic Substance Control Act (TSCA) Interagency Testing Committee (ITC) Priority Testing List, as suspected endocrine distributors. In 2006, U.S. EPA set ambient water quality guidelines for NPs in freshwater at $6.6 \mu \mathrm{g} / \mathrm{L}$ and, in saltwater at $1.7 \mu \mathrm{g} / \mathrm{L}$ (U.S. EPA, 2006). Since 1995, England, France, Germany, and the Scandinavian countries have voluntarily ban NPEOs use in household cleaning products (Renner, 1997). A European Union (EU) initiative, regulating biosolids, established a $50-\mathrm{mg} / \mathrm{kg}$ limit for the total of NPs, NP1EOs and NP2EOs (European Union, 2000). The Danish Ministry of Environment and Energy currently regulates NPs, NP1EOs and NP2EOs in biosolids; the current cut-off limit is $10 \mathrm{mg} / \mathrm{kg}$ (Jensen and Jepsen, 2005). The U.S. consumes approximately 60\% (154,000 tones) of the estimated global annual NPEO production (Soares, et al., 2008). After use these surfactants enter waste streams, are subjected to partial microbial degradation and eventually enter sewage sludge. Due to their presumed rapid mineralization once land-applied, their levels are unrestricted in U.S. biosolids. Also, NPs and the shorter chain NPEOs are lipophilic, indicating limited movement once land-applied. However, reports of their presence in ground and drinking water suggest they may be present in runoff from biosolids applied-fields. To evaluate the persistence and migration of NPEO-byproducts on pasturelands, two biosolids (anaerobic and aerobic/lime stabilized) were land-applied and then analyzed for NPs, 
NP1EOs, and NP2EOs over a six-month period (0,50 and 175-days after application). Artificial rainfall was also applied to these plots (on day-50 and -175) and runoff was collected and analyzed to evaluate NPEO-byproducts and potential surface migration during rain-events.

\section{SAMPLE COLLECTION}

The study plot was a pasture-field located in central; Virginia, U.S. Soils in the research plot are classified as Poindexter sandy clay loam (fine-loamy, mixed, active, thermic Typic Hapludalfs) and Appling sandy clay loam (fine, kaolinitic, thermic Typic Kanhapludults). Soils of the Poindexter series are moderately deep to weathered bedrock and drain well. Soils of the Appling series consist of very deep, well-drained, moderately permeable soils on ridges and side slopes of the Piedmont uplands. Particle-size distribution of the top $30 \mathrm{~cm}$ of the soil horizon consisted of 22 percent clay, 21 percent silt, and 57 percent sand. Surface soil $(0-5 \mathrm{~cm})$ properties were: $\mathrm{pH}$ 6.6, ECEC (effective cation exchange capacity) $7 \mathrm{cmol} / \mathrm{kg}$ and organic matter ranged from 3 to 9 percent.

Study field plots ( $2 \mathrm{~m}$ wide by $2 \mathrm{~m}$ long, average plot slop 8.7 percent) were prepared by installing metal borders to a depth of $15-\mathrm{cm}$ along the designed plot boundaries. Each plot was divided into two sub-plots (A and B each $2 \mathrm{~m} \times 1 \mathrm{~m}$ ) by installing an additional metal border through the middle. The metal borders prevented water movement into or from adjacent plots. A gutter with a pipe outlet was constructed at the base of each subplot to direct the surface runoff to a collection tank (Figure 1.). Field plots were prepared as either a control or a biosolids treatment, receiving one of the two biosolids selected for the study. These biosolids originated from sludges from two U.S. metropolitan areas located on the Atlantic- coast. The sludges were subjected to two different treatment processes (aerobic degradation followed by liming for odor control and anaerobicstabilization). Both were classified as "B" biosolids under U.S. Rule 503. Plots were set up in triplicate; each treatment within the plots was randomly assigned. A side-flinger was used to apply the biosolids to the plots. Application rates averaged 55,000 kg/ha-wet weight. All plots were planted with tall fescue (Festuca arundinacea) and were wellestablished pastures for beef production prior to biosolids application. Cattle grazing were not permitted on the plots during the course of the study.

\section{Figure 1 - Study field plot $4 \mathrm{~m}^{2}$ (sub-plots A and B, each $2 \mathrm{~m} \times 1 \mathrm{~m}$ )}

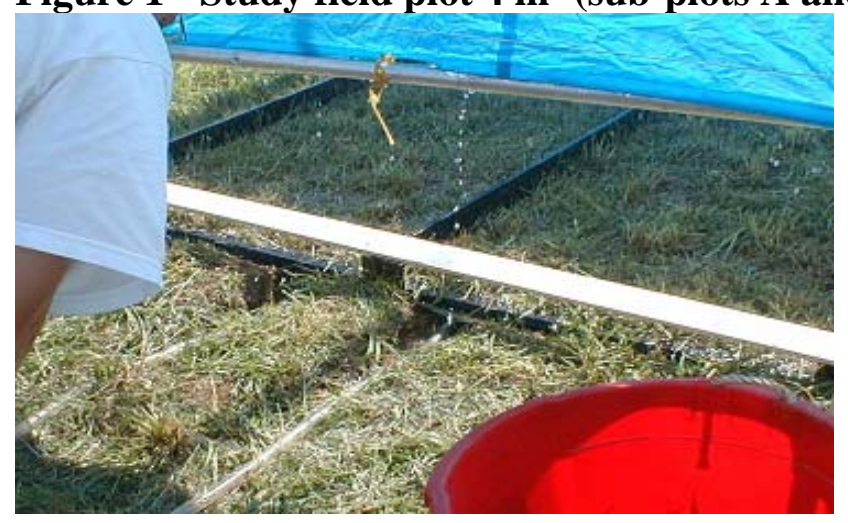


Artificial rainfall, consisting of stream water collected on site was applied at an intensity of $7.5 \mathrm{~cm} / \mathrm{h}$. A buffer zone between each plot was established to prevent cross plot contamination. The grass in each plot was mowed to $\sim 4 \mathrm{~cm}$ in height and pre-wetted the day prior to the artificial rain application. Once runoff was established, it was collected for the first 15 minutes. Four-liter runoff composites were collected from each sub-plot. During each runoff event, surface biosolid aggregates $(>0.5 \mathrm{~cm})$ were randomly collected from outside of each of the six study plots and combined to form two composites (anaerobic and aerobic/limed-stabilized). These were subsequently analyzed for NPs and NPEOs.

\section{ANALYTICAL METHODOLOGY}

Biosolids samples were first freeze-dried and then ground to a powder, stored in glass jars with Teflon ${ }^{\circledR}$ lids at $<4{ }^{\circ} \mathrm{C}$, until analyzed. Percent solids of samples were determined by subtracting the before and after freeze-dried weights. Two preservation procedures were used for the runoff samples. For the first set, taken at day-50, $\mathrm{pH}$ was reduced to $<2$ with concentrated sulfuric acid $\left(\mathrm{H}_{2} \mathrm{SO}_{4}\right)$. Formaldehyde was added at a 50:1 to the second set, collected at day-175. Both sets were stored in 4L amber glass jars with Teflon ${ }^{\circledR}$ lids at $<4{ }^{\circ} \mathrm{C}$ until analyzed. Total and dissolved organic carbon (TOC and DOC) was determined for the 50-day runoff samples. DOC was defined as the portion of sample that passed through a $0.45-\mu \mathrm{m}$ filter. Particulate organic carbon (PtOC) was calculated by subtracting DOC from TOC. TOC and DOC were analyzed by thermal conductivity detection (Exeter CE440, Chelmsford, MA); inorganic carbon was removed by addition of hydrochloric acid.

Biosolids samples (2-5 g) were extracted using an enhanced solvent extraction (Dionex ASE 200, Sunnyvale, CA). Conditions were: two extraction cycles, pressure @ 1000 psi, temperature@100 ${ }^{\circ} \mathrm{C}$, heat 5 minutes, static 5 minutes, 60\% flush, purge 180 seconds with nitrogen. Approximately $30 \mathrm{~mL}$ of dichloromethane (DCM) were used per sample. Perinaphthenone was added as a surrogate prior to extraction. Extracts were reduced to 8 $\mathrm{mL}$ under nitrogen, and then purified by size exclusion chromatography, (Envirosep$\mathrm{ABC}^{\circledR}, 350 \times 21.1 \mathrm{~mm}$. column; Phenomenex, Torrance, $\left.\mathrm{CA}\right)$. The column was eluted with DCM at $5 \mathrm{~mL} / \mathrm{min}$. The first $50 \mathrm{~mL}$, containing high molecular weight lipids, were discarded. The next $60 \mathrm{~mL}$, containing the compounds of interest, were collected and solvent exchanged to hexane and volume reduced to $<1 \mathrm{~mL}$. The partially purified extract was then added to a $2 \mathrm{~g}$ silica glass column (EnviroPrep, Burdick \& Jackson) and eluted with $3 \mathrm{~mL}$ hexane, followed by $6 \mathrm{~mL}$ of 60:40 hexane/DCM to remove possible interfering compounds (e.g. PAHs, PCBs). NPs, and the NPEOs were then eluted with $10 \mathrm{~mL}$ of acetone and collected separately. The retained fraction was reduced in volume and solvent exchanged to toluene. P-terphenyl (10 ng) was added as an internal standard, prior to gas chromatography mass spectrometrometric (GC/MS) analysis. (The NPs/NPEO extraction and purification procedure has been previously described by La Guardia et al. (2001).) 
The runoff samples ( $2 \mathrm{~L} \times 2$ ) were sequentially extracted using a separatory funnel with three aliquots of DCM, totaling $300 \mathrm{~mL}$. Perinaphthenone was added as a surrogate prior to extraction. The extracts were combined, solvent exchanged to hexane, reduced in volume to $<1 \mathrm{~mL}$ and purified by passing through a $2 \mathrm{~g}$ silica SPE column, as previously described for the biosolids. Each sample was reduced and spiked with the internal standard and analyzed by GC/MS.

NPs, NP1EOs and NP2EOs were separated by GC and identified with a mass spectrometer (Varian Saturn 2000 GC/MS, Walnut Creek, CA) operated in the electron ionization (EI) mode, scanning from 50 to $450 \mathrm{~m} / \mathrm{z}$. The analytical $\mathrm{GC}$ column used was a $60 \mathrm{~m}, \mathrm{DB}-5$ (Agilent J\&W GC Column, Folsom, CA) with $0.25 \mu \mathrm{m}$ film thickness and $0.32 \mathrm{~mm}$ inner diameter. As per La Guardia et al. (2001) and Sánchez-Avila, et al. (2009), ions selected for compound quantification were: NPs $135 \mathrm{~m} / \mathrm{z}$, NP1EOs $179 \mathrm{~m} / \mathrm{z}$, NP2EOs $223 \mathrm{~m} / \mathrm{z}$, perinaphthenone 152 and $180 \mathrm{~m} / \mathrm{z}$, and p-terphenyl $230 \mathrm{~m} / \mathrm{z}$. Analytes were quantified with a five-point linear calibration curve generated with analytical standards consisting of nonylphenols (Fluka Chemie AG, Switzerland) and a 60:40 mix NP1EOs and NP2EOs (ChemService, West Chester, PA). Quantitation limits for biosolids were $0.1 \mathrm{mg} / \mathrm{kg}$ for NPs, $0.25 \mathrm{mg} / \mathrm{kg}$ for NP1EOs and $0.15 \mathrm{mg} / \mathrm{kg}$ for NP2EOs. Limits were $50 \mathrm{ng} / \mathrm{L}$ for NPs, NP1EOs and NP2EOs each for the runoff samples. Blanks were analyzed with each sample set. Surrogate recoveries ranged from 73 to $108 \%$ and results for all blanks were below detection limit.

Statistical analysis was conducted on the runoff samples using SigmaStat 2.0 (Jandel Corporation). A one-way analysis of variance (ANOVA) was used to test if there was a significant difference in NPs, NP1EOs and NP2EOs between the three treatments (control, anaerobic and aerobic/lime). Post hoc Tukey tests for unequal samples was performed to evaluate differences between treatments and was considered significant at the $95 \%$ confidents level, $\mathrm{P}<0.05$.

\section{RESULTS}

\section{Weathering effects of biosolids NPEOs-degradation products}

NPs, NP1EOs and NP2EOs were detected in the anaerobic and aerobic/lime-stabilized biosolids used in this study, totals were 972 and $494 \mathrm{mg} / \mathrm{kg}$, d.w., respectively (Table 1). These concentrations are similar to other U.S. biosolids, previously reported by La Guardia et al. (2001) and Pryor et al. (2002). It has also been reported that anaerobic treatment process favors degradation of the polyethoxylates to NPs (Ahel et al., 1994). This was supported by the lower NP/ethoxylate ratios in the aerobic/lime compared to the anaerobic biosolids (Figure 2), i.e. the NPs concentration was approximately 15 times higher in the anaerobic sample verses the aerobic/lime sample (843 and $59 \mathrm{mg} / \mathrm{kg}$, respectively). The NP1EOs concentration in the aerobic/lime biosolids was nearly four times that in the anaerobic-stabilized biosolids, 413 versus $119 \mathrm{mg} / \mathrm{kg}$ (Figure 2), respectively. These ethoxylates may be subject to further degradation, if conditions are appropriate, increasing NP concentrations in the aerobic/lime applied fields. NP2EOs 
were over two-fold greater in the aerobic biosolids sample (22 $\mathrm{mg} / \mathrm{kg})$ compared to the anaerobic biosolids $10 \mathrm{mg} / \mathrm{kg}$.

Table 1 - NPs and NPEOs concentrations (mg/kg, d.w.) in biosolids at time of application and weathered (day-50, -175) biosolids aggregates from the field $(>0.5$ cm).

\begin{tabular}{|c|c|c|c|c|c|}
\hline \multicolumn{2}{|c|}{ Samples } & NP & \multicolumn{3}{|c|}{ (mg/kg, d. w.) } \\
\hline \multirow{2}{*}{ applied } & anaerobic & 843 & 119 & 10 & 972 \\
\hline & aerobic/lime & 59 & 413 & 22 & 494 \\
\hline \multirow{2}{*}{ day-50 } & anaerobic & 664 & 38 & 3 & 705 \\
\hline & aerobic/lime & 117 & 438 & 11 & 556 \\
\hline \multirow{2}{*}{$\underline{\text { day- }-175}$} & anaerobic & 70 & 3 & nd & 73 \\
\hline & aerobic/lime & 2 & 6 & nd & 8 \\
\hline
\end{tabular}

(nd $=$ non-detect)

Figure 2 - Concentrations of NPs and NPEOs (mg/kg, d.w.) in biosolids prior to land-application.

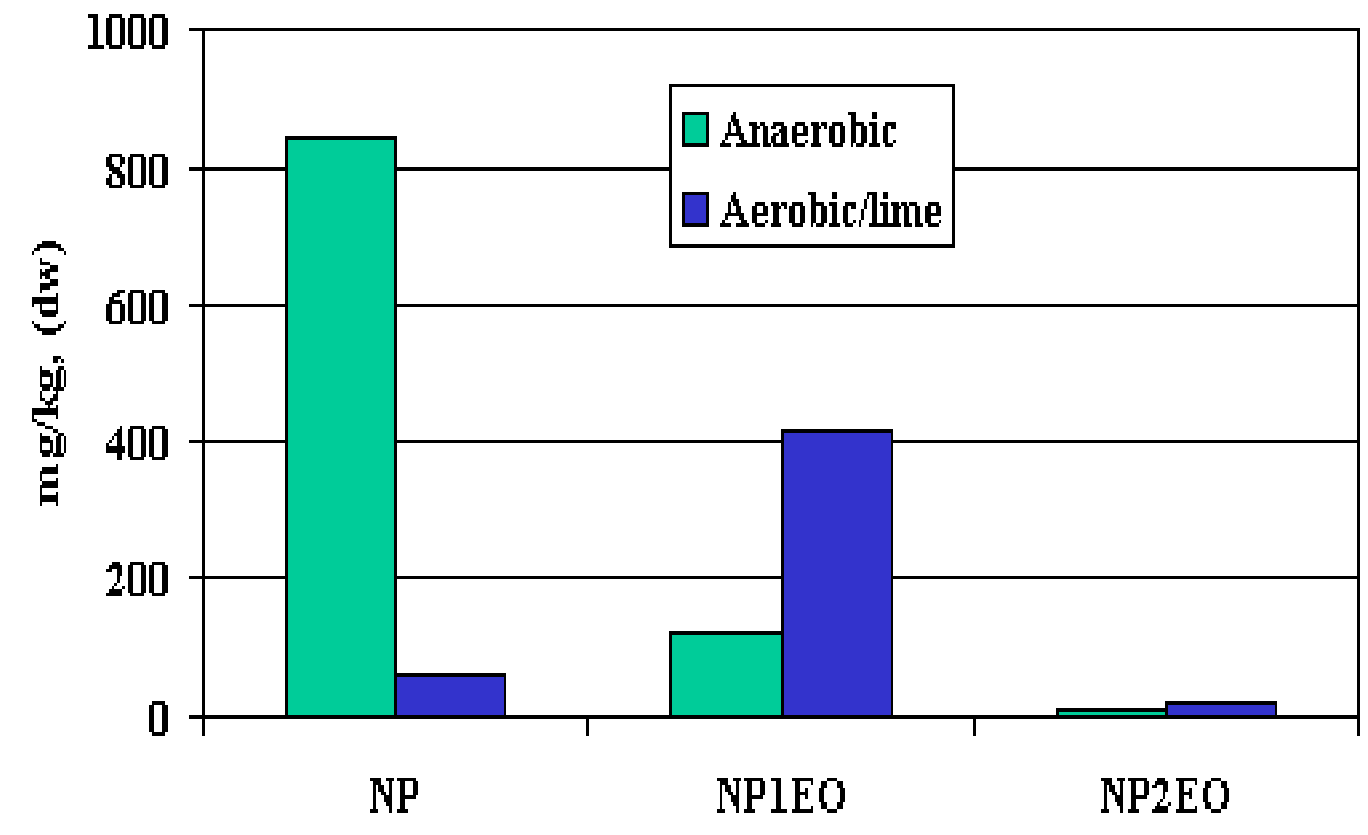

After these biosolids were applied to the test-pasture plots they were subjected to prolonged environmental weathering under realistic agricultural conditions. After 50days of exposure, NPEO-byproducts concentrations in the anaerobic samples decreased by $27 \%$ (Figure $3 \mathrm{a}$ ). However, concentrations in the aerobic/limed aggregates exposed to the same conditions, increased by $12 \%$ (Figure $3 \mathrm{~b}$ ). This may be related to subsequent degradation of the higher ethoxylates (e.g. > NP2EO) present in the aerobic/lime sample. NPs increased nearly two-fold in the aerobic/lime-stabilized biosolids (Figure 3b) and even though NPs in the anaerobic biosolids decreased by $21 \%$ they were still present at 
$664 \mathrm{mg} / \mathrm{kg} 50$ days after application (Figure 3a). On day-175 (175 days after application), there was a significant decrease $(>90 \%)$ in the amount of NPEO-byproducts in the anaerobic and aerobic biosolids, 73 and $8 \mathrm{mg} / \mathrm{kg}$ respectively (Figure 3a, and 3b).

Figures 3a - NPs and NPEOs concentrations (mg/kg, d.w.) in anaerobic biosolids at 50 and 175 days following land application.

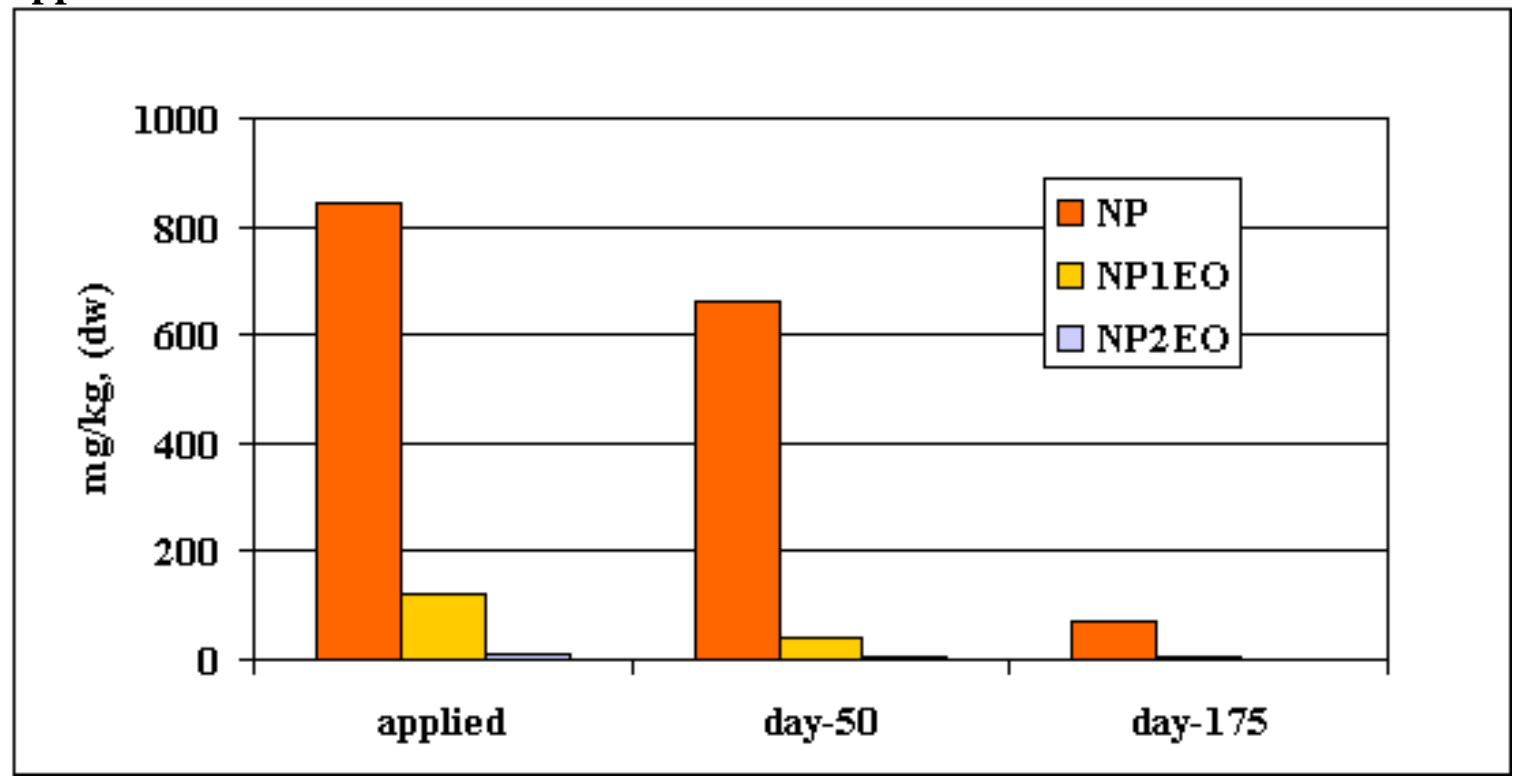

Figure 3b - NPs and NPEOs concentrations (mg/kg, d.w.) in aerobic/lime biosolids at 50 and 175 days following land application.

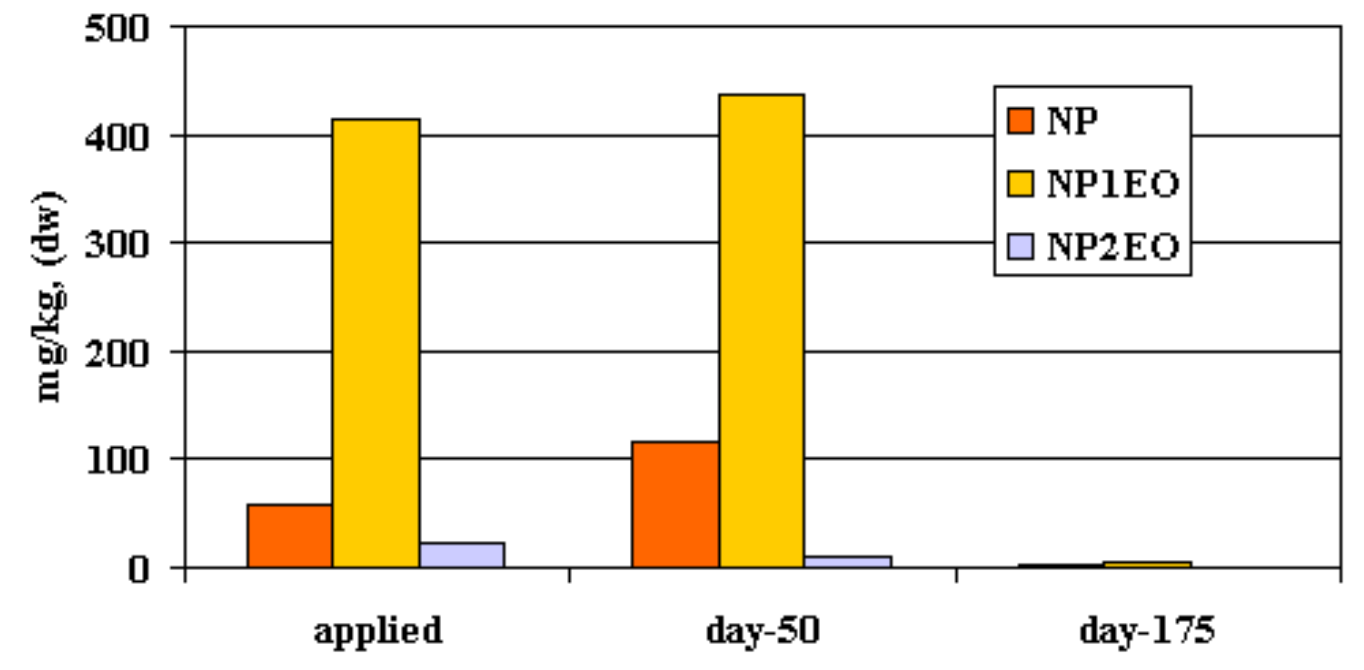

U.S. EPA Rule 503 restricts grazing on biosolids applied fields for 30 days (U.S. EPA, 1993). Under the conditions within our study it appears that grazing animals could be 
exposed to these xenoestrogenic compounds if they ingest aggregates for at least six months post-application. These findings support the laboratory study conducted by Hesselsoe, et al. (2001), who postulated that NPs would be present within the center of 2$\mathrm{cm}$ sludge aggregates for more than a year.

\section{NPs and NP1EOs in runoff collected after artificial rainfall}

NPs were detected in the 50- and 175-day runoff samples from both biosolids treatments, mean concentrations ranged from 1.69 to $5.35 \mu \mathrm{g} / \mathrm{L}$ (Table $2 \mathrm{a}, 2 \mathrm{~b}$ ). NP1EOs were only detected in the runoff from the aerobic/lime-stabilized biosolids on day 50, at $1.57 \mu \mathrm{g} / \mathrm{L}$ and NP2EO was not detected in either treatments or at either collection times (Table 2a, $2 b$ ). The day-50 runoff sample from the anaerobic stabilized biosolids exhibited the highest average concentration of NPs, i.e. $5.35 \mu \mathrm{g} / \mathrm{L}$, compared to lime stabilized and control contained 3.82 and $2.54 \mu \mathrm{g} / \mathrm{L}$, respectively. During the course of the study all plots were left uncovered and open to the environment, which may account for NPs in the controls. Previous researchers have detected NPs in air samples (Dachs et al., 1999). However, accidental contamination during biosolids application or during the course of the study is a more likely scenario. Nevertheless, a one-way analysis of variance (ANOVA) on the runoff samples showed that there was a statistical difference between the three treatments. A pair-wise multiple comparison (Turkey Test) shown that the anaerobic stabilized runoff was statistically greater than the control $(\mathrm{P}<0.05)$ at day-50 (Figure 4, indicated by *), while the aerobic/limed plot runoff was not. However, the aerobic/limed biosolids had nearly 10-times more NP1EOs than the anaerobic stabilized

Table 2a - NPs and NPEOs and organic carbon (DOC, PtOC and TOC) concentrations in runoff ( $(0-15 \mathrm{~min})$ 50-days after biosolids application.

\begin{tabular}{|c|c|c|c|c|c|c|}
\hline Samples & NP & $\begin{array}{c}\text { NP1EO } \\
(\mu g / L)\end{array}$ & NP2EO & DOC & $\begin{array}{r}\text { PtOC } \\
(\mathrm{mg} / \mathrm{L})\end{array}$ & TOC \\
\hline control (rep 1, plot a) & 2.85 & nd & nd & 17.630 & 5.914 & 23.544 \\
\hline control (rep 2, plot a) & 1.89 & nd & nd & 26.950 & 8.663 & 35.613 \\
\hline control (rep 2, plot b) & 2.98 & nd & nd & 40.170 & 4.736 & 44.906 \\
\hline control (rep 3, plot a) & 0.96 & nd & nd & 16.430 & 6.766 & 23.196 \\
\hline control (rep 3, plot b) & 2.01 & nd & nd & 14.760 & 2.106 & 16.866 \\
\hline Mean & 2.54 & $* * *$ & $* * *$ & 27.357 & 6.127 & 33.484 \\
\hline$\%$ Standard Deviation $(\% \mathrm{SD})$ & 48.2 & $* * *$ & $* * *$ & 50.953 & 40.633 & 45.457 \\
\hline anaerobic (rep 1, plot a) & 4.47 & nd & nd & 19.080 & 10.220 & 29.300 \\
\hline anaerobic (rep 2, plot a) & 4.70 & nd & nd & 36.120 & 9.992 & 46.112 \\
\hline anaerobic (rep 2, plot b) & 8.78 & nd & nd & 26.210 & 12.221 & 38.431 \\
\hline anaerobic (rep 3, plot a) & 3.68 & nd & nd & 22.510 & 7.772 & 30.282 \\
\hline anaerobic (rep 3, plot b) & 5.11 & nd & nd & 14.530 & 6.940 & 21.470 \\
\hline Mean & 5.35 & $* * *$ & $* * *$ & 22.463 & 9.212 & 31.675 \\
\hline$\% \mathrm{SD}$ & 37.2 & $* * *$ & $* * *$ & 35.196 & 21.212 & 28.862 \\
\hline aerobic/lime (rep 1, plot a) & 3.71 & 1.83 & nd & 47.170 & 7.630 & 54.800 \\
\hline aerobic/lime (rep 1, plot b) & 4.73 & 1.55 & nd & 19.630 & 10.673 & 30.303 \\
\hline aerobic/lime (rep 2, plot a) & 2.80 & 1.37 & nd & 40.730 & 8.103 & 48.833 \\
\hline aerobic/lime (rep 2, plot b) & 4.84 & 1.80 & nd & 29.200 & 12.158 & 41.358 \\
\hline aerobic/lime (rep 3, plot b) & 3.01 & 1.32 & nd & 20.980 & 11.382 & 32.362 \\
\hline Mean & 3.82 & 1.57 & $* * *$ & 31.542 & 9.989 & 41.531 \\
\hline$\% \mathrm{SD}$ & 24.8 & 15 & $* * *$ & 38.425 & 20.168 & 25.241 \\
\hline artificial rain water (rep-1) & 0.24 & nd & nd & 8.920 & 0.870 & 9.790 \\
\hline artificial rain water (rep-2) & 0.23 & nd & nd & 4.610 & 0.655 & 5.265 \\
\hline Mean & 0.24 & $* * *$ & $* * *$ & 6.765 & 0.763 & 7.528 \\
\hline$\% \mathrm{SD}$ & 3.1 & $* * *$ & $* * *$ & 8.920 & 19.938 & 42.506 \\
\hline
\end{tabular}


biosolids at day-50. This was reflected in the elevated concentration of NP1EOs (1.57 $\mu \mathrm{g} / \mathrm{L}$ ) in the runoff sample (Table 2a). Statistical analyses (ANOVA and Turkey Test) concluded that NP1EO in the aerobic/limed sample was significantly greater than the control $(\mathrm{P}<0.05)$ (Figure 4 indicated by $* *)$. The 175-day runoff samples derived from both the aerobic/limed and anaerobic stabilized biosolids plots had elevated levels of NPs compared to the control, $2.36 \mu \mathrm{g} / \mathrm{L}, 1.69 \mu \mathrm{g} / \mathrm{L}$ and $1.37 \mu \mathrm{g} / \mathrm{L}$, respectively. But, statistical analysis did not show a significant difference between the applied and controlled plots. Also, NP runoff levels for both treatments did drop at day-175 compared to the 50-day treatment, but the aerobic/limed stabilized was only reduced by $21 \%$ compared to $68 \%$ for the anaerobic sample (Figure 4 ). This may be an indication of the higher ethoxylates (e.g. NP1EO) undergoing degradation to NPs on the soil surface, thereby replenishing NPs, which may have mineralized.

Table 2b - NPs and NPEOs concentrations in runoff ( 0 - 15 min) 175-days after biosolids application

\begin{tabular}{r|ccc}
\hline Samples & NP & $\begin{array}{c}\text { NP1EO } \\
(\boldsymbol{\mu g} / \mathbf{L})\end{array}$ & NP2EO \\
\hline control (rep 1, plot b) & 1.81 & nd & nd \\
control (rep 2, plot b) & 1.11 & nd & nd \\
control (rep 3, plot b) & 1.19 & nd & nd \\
Mean & 1.37 & $* * *$ & $* * *$ \\
& 27.9 & & $* * *$ \\
anaerobic (rep 1, plot b) & 1.55 & nd & nd \\
anaerobic (rep 2, plot b) & 1.21 & nd & nd \\
anaerobic (rep 3, plot b) & 2.32 & nd & nd \\
Mean & 1.69 & $* * *$ & $* * *$ \\
\%SD & 33.5 & & $* * *$ \\
& & & nd \\
aerobic/lime (rep 1, plot b) & 2.04 & nd & nd \\
aerobic/lime (rep 2, plot b) & 1.70 & nd & nd \\
aerobic/lime (rep 3, plot b) & 1.82 & $* * *$ & $* * *$ \\
Mean & 2.36 & $* * *$ & $* * *$ \\
\%SD & 17.9 & & nd \\
& & nd & nd \\
artificial rain water (rep-1) & 0.22 & nd & $* * *$ \\
artificial rain water (rep-2) & 0.23 & $* * *$ & $* * *$ \\
Mean & 0.23 & & \\
\hline \%SD & 3.9 & &
\end{tabular}


Figure 4., Analysis of NPs and NP1EOs in simulated runoff, 50 and 175-days after biosolids application

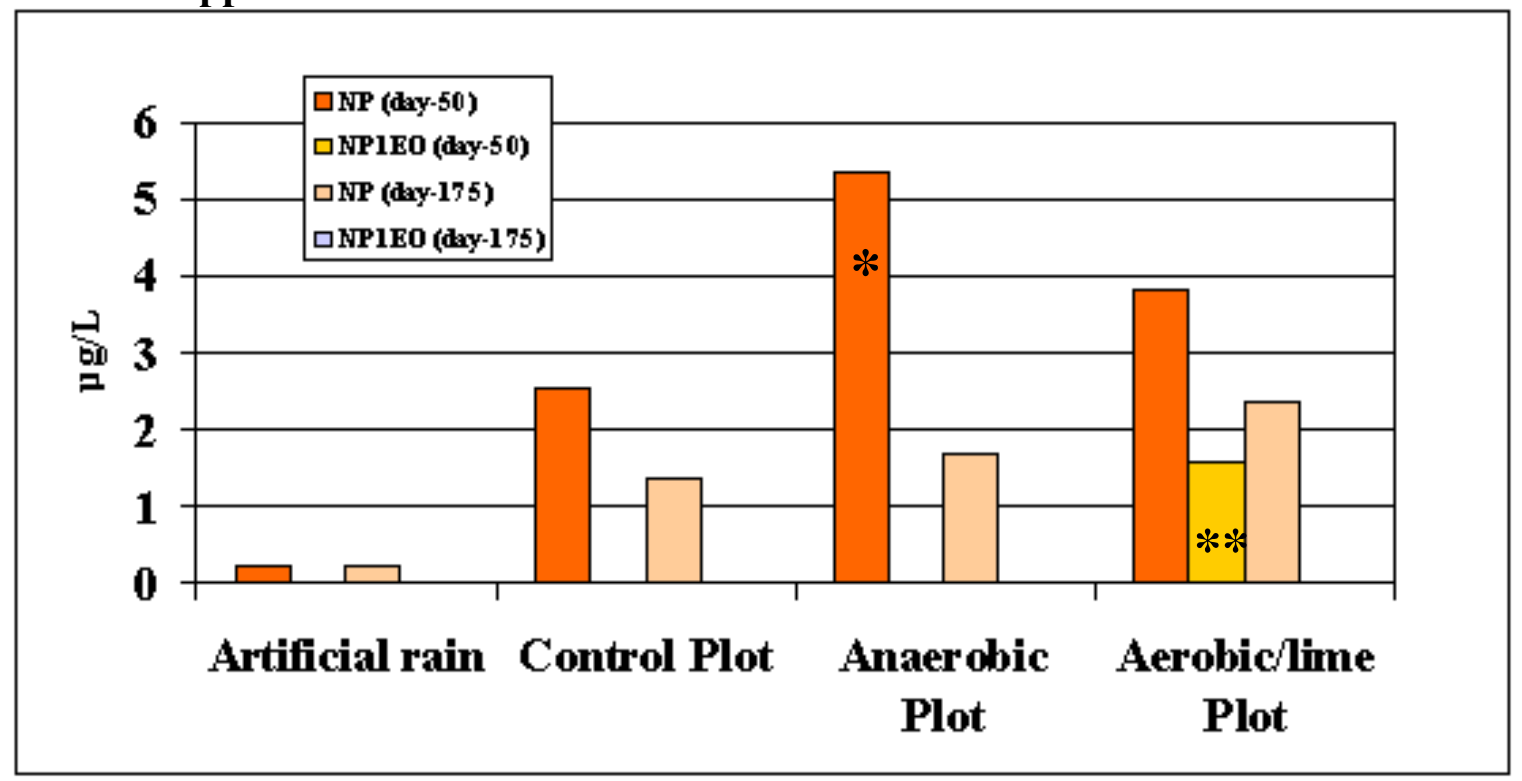

(* and ** indicate significant difference, $\mathbf{P}<0.05$ )

\section{NP association with particulate organic carbon (PtOC) in runoff}

NPs and NPEOs in the runoff samples were detected below their water solubility of 5 and $3 \mathrm{mg} / \mathrm{L}$, respectively (Ahel and Giger, 1993) during the course of this study (Table 2a, $2 b$ ). However, NPs and NP1EOs have $\log \mathrm{K}_{\text {ows }}$ of 4.48 and 4.17, respectively, indicating their hydrophobic characteristics. NP concentrations in runoff samples collected on day50 were better correlated with PtOC $\left(\mathrm{R}^{2}=0.562\right)$ than TOC $\left(\mathrm{R}^{2}=0.252\right)$ or DOC $\left(\mathrm{R}^{2}=\right.$ 0.125 ) (Figure 5). This, in combination with its fairly high $K_{\text {ow }}$, suggests the potential for association with particulates within the sample. Particle-associated NPs would be expected to exhibit lower migration potential than freely dissolved NPs. NPs were also detected water from the stream adjacent to the pastureland study plots on day-50 and $175,0.24$ and $0.23 \mu \mathrm{g} / \mathrm{L}$, respectively (Table $2 \mathrm{a}, 2 \mathrm{~b}$ ). The amount of artificial rainwater required for this study was large (greater than 10,000 liters). For logistics and cost, a natural stream located adjacent to the study-plot pasture was chosen as a water source. The rural and agricultural lands upstream of the study site were believed free of industrial, residential or agricultural outfalls (point sources). These levels may indicate that NPs may have already migrated to surrounding aquatic environments from adjacent fields previously receiving biosolids. However, non-point sources (e.g. atmospheric deposition) or the use of agricultural chemicals (e.g. herbicides or pesticides) containing these surfactants cannot be ruled out. The NP concentrations observed in the current study were below the reporting level $(<0.50 \mu \mathrm{g} / \mathrm{L}, \mathrm{NPs})$ of 139 U.S. streams studied in 1999-2000 (Kolpin et al., 2002). However, they exceeded 70\% ( $>0.11 \mu \mathrm{g} / \mathrm{L})$ of an early 1989 study of 30 U.S. Rivers, all receiving municipal or industrial wastewater (Naylor et al., 1992). 
Figure 5 - NPs and PtOC concentrations of the runoff samples collected on day-50

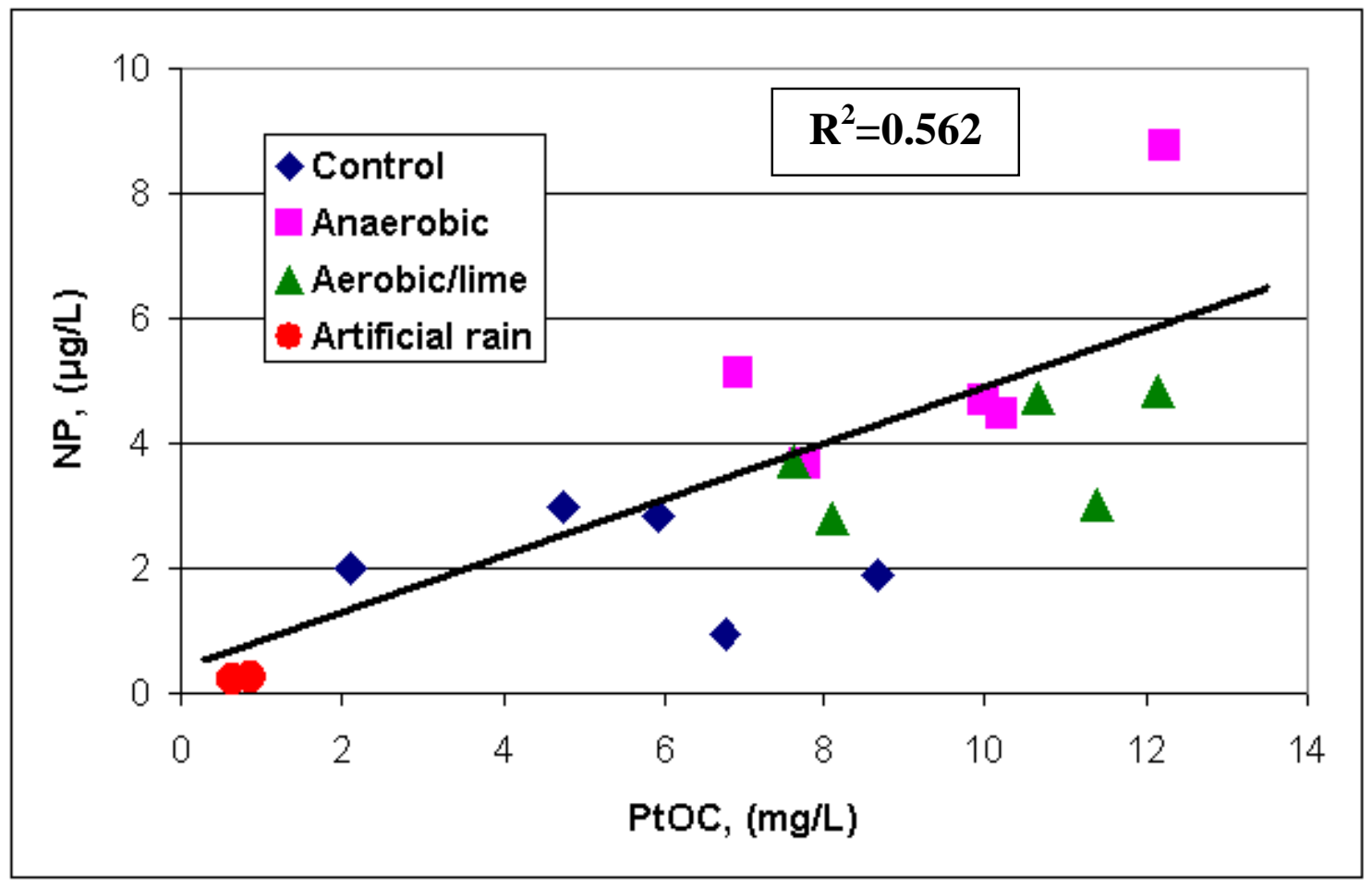

\section{CONCLUSION}

Biosolids can contain up to $\mathrm{g} / \mathrm{kg}$ (d.w.) of NPEO degradation products (NPs, NP1EOs and NP2EOs). Treatment type (e.g. anaerobic or aerobic/lime) may influence NPEObyproduct concentrations, e.g. wastewater treatment processes utilizing anaerobic digestion favor production of NPs. Once land-applied NPEO-byproducts appeared to continue to degrade. However, detectable biosolid aggregate concentrations were observed six-months after application, $>8-\mathrm{mg} / \mathrm{kg}$, (d.w.). This was approximately 2 to $8 \%$ of the original concentrations. In contrast, 50 -days after application, $72 \%$ of NPEOsbyproducts were detected for the anaerobic biosolids. For the aerobic/lime biosolids, 50days post-application, concentrations increased by $12 \%$. This might be due to contributions from further degradation of the higher ethoxylates (e.g. > NP2EO) within the sample. This may be of concern to grazing animals, which under the current U.S. EPA's 503 Rule, are permitted to graze on pasturelands 30-days after biosolids application.

Runoff produced by artificial rainfall also contained NPs, on day-50, 5.35 and $3.82-\mu \mathrm{g} / \mathrm{L}$ and on day-175, 1.69 and $2.36-\mu \mathrm{g} / \mathrm{L}$ from anaerobic and aerobic/lime treated plots, respectively. NP1EOs were only detected in the day-50 sample $(1.57-\mu \mathrm{g} / \mathrm{L})$ from the aerobic/lime plot. Relatively hydrophobic NPs may have been associated with solids from the day-50 runoff samples from both the aerobic and aerobic/lime plots. This, plus 
the requirement for buffer zones between biosolids application sites and perennial streams, may limit transport to surface waters. However, as biosolids organic carbon is depleted, surviving NPEO-byproducts may be released during continued rainfall-events. The U.S. EPA's NP aquatic life ambient water one-hour quality criteria is $28-\mu \mathrm{g} / \mathrm{L}$ for freshwater and $7.0-\mu \mathrm{g} / \mathrm{L}$ for saltwater, (U.S. EPA, 2006). These are only slightly above our observed maximum runoff value of $5.35-\mu \mathrm{g} / \mathrm{L}$. This indicates the need for additional studies of the agricultural application of biosolids, including monitoring of streams and ephemeral water bodies (essential breeding habitats of amphibians).

\section{REFERENCES}

Ahel, M. and Giger, W. (1993) Partitioning of Alkylphenols and Alkylphenol Polyethoxylates Between Water and Organic Solvents. Chemosphere, 26, 14711478.

Ahel, M.; Giger, W.; Koch, M. (1994) Behavior of Alkyphenol Polyethoxylate Surfactants in the Aquatic Environment. I. Occurrence and Transformation in Sewage-treatment, Wat. Res., 28, 1131 - 1142.

Clark, L. B.; Rosen, R. T.; Hartman, T. G.; Louis, J. B.; Suffet, I. H.; Lippincott, R. L.; Rosen, J. D. (1992) Determination of Alkylphenol Ethoxylates and Their Acetic Acid Derivatives in Drinking Water by Particle Beam Liquid Chromatography/Mass Spectrometry. Intern. J. Environ. Analyt. Chem., 47, 167 180.

Dachs, J.; Van Ry, D. A.; Eisenreich, S. J. (1999) Occurrence of Estrogenic Nonylphenols in the Urban nad Coastal Atmosphere of the Lower Hudson River Estuary. Environ. Sci. Technol., 33, 2676 - 2679.

Danish Environmental Protection Agency (1998) Effects of Organic Chemicals in Sludge Applied to Soil: Degradation and Toxicity to Organisms Living in Soil; Ministry of Environment and Energy; Denmark.

Environment Canada (1998) Alkylphenol Ethoxylate Persistence in Biosolids Treated Field Soil Project 71773; Environment Canada and National Water Research Institute; Canada.

European Union (2000) Working Document on Sludge $3^{\text {rd }}$ Draft ENV.E.3/LM; Europa European Commission; Belgium

Fairchild, W. L.; Swansburg, E. O.; Arsenault, J. T.; Brown, S. B. (1999) Does an Association Between Pesticide Use and Subsequent Declines in Catch of Atlantic Salmon (Salmo salar) Represent a Case of Endocrine Disruption? Environ. Health Perspect., 107, 349 - 358. 
Gray, M. A. and Metcalfe, C. D. (1997) Induction of Testis-ova in Japanese Medaka (Oryzias Latipes) Exposed to p-Nonylphneol. Environ. Toxicol. Chem., 16, 1082 $-1086$.

Hale, R. C.; Smith, C. L.; De Fur, P.; Harvey, E.; Bush, E. O.; La Guardia M. J.; Vadas, G. G. (2000) Nonylphenols in Sediments and Effluents Associated with Diverse Wastewater Outfalls. Environ. Toxicol. Chem., 19, 946 - 952.

Harries, J. E.; Hill, R. E.; Harris, C. A.; Maddix, S.; Sumpter, J. P.; Tyler, C. R. (2000) Development of a Reproductive Performance Test for Endocrine Disrupting Chemicals Using Pair-Breeding Fathead Minnows (Pimephales promelas). Environ. Sci. Technol., 34, 3003 - 3011.

Hesselsoe, M., Jensen, D., Skals, K., Olsen,T., Moldup, P., Roslev, P., Mortensen,G. K., Henriksen, K. (2001) Degradation of 4-Nonylphenol in Homogeneous and Nonhomogeneous Mixtures of Soil and Sewage Sludge. Environ. Sci. Technol., 35, 3695-3700.

Jensen, J. and Jepsen S. (2005) The Production, Use and Quality of Sewage Sludge in Denmark. Waste Management 25, 239 - 247.

Jobling, S.; Sheahan, D.; Osborne, J. A.; Matthiessen, P.; Sumpter, J. P. (1996) Inhibition of Testicular Growth in Rainbow Trout (Oncorhynchus Mykiss) Exposed to Estrogenic Alkylphenolic Chemicals. Environ. Toxicol. Chem,. 2, 194 - 202.

Kinney, C. A.; Furlong, E. T.; Zaugg, S. D.; Burkhardt, M. R.; Wearner, S. L.; Cahill, J. D.; Jorgensen, G. R. (2006) Survey of Organic Wastewater Contaminants in Biosolids Destined for Land Application. Environ. Sci. Technol., 40, 7207 - 7215.

Kolpin, D. W.; Furlong, E. T.; Meyer, M. T.; Thurman, E. M.; Zaugg, S. D.; Barber, L. B.; Buxton, H. T. (2002) Pharmaceuticals, Hormones, and Other Organic Wastewater Contaminants in U.S. Streams, 1999-2000: A National Reconnaissance. Environ. Sci. Technol., 36, 1202 - 1211.

Kuch, H. M. and Ballschmiter K. (2001) Determination of Endocrine-Disrupting Phenolic Compounds and Estrogens in Surface and Drinking Water by HRGC(NCI)-MS in the Picogram per Liter Range. Environ. Sci. Technol., 35, 3201 3206.

La Guardia, M. J.; Hale, R. C.; Harvey, E. P.; Mainor, T. M. (2001) Alkylphenol Ethoxylate Degradation Products in Land-Applied Sewage Sludge (Biosolids). Environ. Sci. Technol., 35, 4798 - 4804.

Mann R. M.; Bidwell, J. R. (2001) The Acute toxicity of Agricultural Surfactants to the Tadpoles of Four Australian and Two Exotic Frogs. Environ. Poll., 114, 195 - 
205.

National Research Council (2002) Biosolids Applied to Land: Advancing Standards and Practices National Academy Press, Washington, D.C., USA

Naylor, C. G.; Mieure, J. P.; Adams, W. J.; Weeks, J. A.; Castaldi, F. J.; Ogle, L. D.; Romano, R. R. (1992) Alkylphenol Ethoxylates in the Environment. Journal of the American Oil Chemists Society, 69, 605-703.

Öman, C. and Hynning, P. (1993) Identification of Organic Compounds in Municipal Landfill Leachates. Environ. Pollution, 80, 265 - 271.

Paul, C.; Rhind, S. M.; Kyle, C. E.; Scott, H.; McKinnell, C.; Sharpe, R. M. (2005) Cellular and Hormonal Disruption of Fetal Testis Development in Sheep Reared on Pasture Treated with Sewage Sludge. Environ. Health Perspect., 113, 1580 1587.

Pryor, S. W.; Hay A. G.; Walker, L. P. (2002) Nonylphenol in Anaerobically Digested Sewage Sludge from New York State. Environ. Sci. Technol., 36, 3678 - 3682.

Renner, R. (1997) European Bans on Surfactant Trigger Transatlantic Debate. Environ. Sci. Tech. 31, 316a - 320a.

Routledge, E. J. and Sumpter, J. P. (1997) Structural Features of Alkylphenolic Chemicals Associated with Estrogenic Activity. J. Biol. Chem., 272, 3280 - 3288.

Rudel, R. A.; Melly, S. J.; Geno, P. W.; Sun G.; Brody, J. G. (1998) Identification of Alkylphenols and Other Estrogenic Phenolic Compounds and Wastewater, Septage, and Groundwater on Cape Cod, Massachusetts. Environ. Sci. Technol., 32, $861-869$.

Sánchez-Avila, J.; Bonet J.; Velasco, G.; Lacorte, S. (2009) Determination and Occurrence of Phathalates, Alklphenols, Bisphenol-A, PBDEs PCBs and PAHs in an Industrial Sewage Grid Discharging to a Municipal Wastewater Treatment Plant. Sci. Total Environ., (article in press).

Shang, D. Y.; Macdonald, R. W.; Ikonomou, M. G. (1999) Persistence of Nonylphenol Ethoxylate Surfactants and Their Primary Degradation Products in Sediments from near a Municipal Outfall in the Strait of Georgia, British Columbia, Canada. Environ. Sci. Technol., 33, 1366 - 1372.

Soares, A.; Guieysse, B.; Jefferson, B.; Cartmell, E.; Lester, J. N. (2008) Nonylphenol in the Environment: A Critical Review on Occurrence, Fate, Toxicity and Treatment in Wastewaters. Environ. Intern., 34, 1033 - 1049. 
Soto, A, M.; Sonnenschein, C.; Chung, K. L.; Fernandez, M. F.; Olea, N.; Serrano, F. O. (1995) The E-Screen Assay as a Tool to Identify Estrogens: An Update on Estrogenic Environmental Pollutants. Environ. Health. Persp. Suppl., 103, 113 122.

Tamage, S. S. (1994) Environmental and Human Safety of Major Surfactants, Alcohol Ethoxylates and Alkylphenol Ethoxylates; Lewis Publisher, USA.

Thomas, K. V.; Hurst, M. R.; Matthiessen, P.; Sheahan, D.; Williams, R. J. (2001) Toxicity Characterization of Organic Contaminants in Stormwaters from an Agricultural Headwater Stream in South East England. Wat. Res., 35, 2411 2416.

Topp, E. and Starratt, A. (2000) Rapid Mineralization of the Endocrine-Disrupting Chemical 4-Nonylphenol in Soil. Environ. Toxicol. Chem., 19, 313 - 318.

U.S. Environmental Protection Agency (1993) The Standards for the Use or Disposal of Sewage Sludge, Title 40 CFR, Part 503. February 19, 1993.

U.S. Environmental Protection Agency (2006) Aquatic Life Ambient Water Quality Criteria- Nonylphenol - Final, EPA-822-R-05-005. Office of Water, Washington, D.C., USA.

U.S. Environmental Protection Agency (2009) Targeted National Sewage Sludge Survey Statistical Analysis Report, EPA-822-R-08-018. Office of Water, Washington, D.C., USA

Yamashita, N.; Kannan, K.; Imagawa, T.; Villeneuve, D.; Hasimoto, S.; Miyazaki, A.; Giesy, J. P. (2000) Vertical Profile of Polychlorinated Dibenzo-p-dioxins, Dibenzofurans, Naphthalenes, Biphenyls, Polycyclic Aromatic Hydrocarbons, and Alkylphenols in a Sediment Core from Tokyo Bay, Japan. Environ. Sci. Technol., 34, 3560 - 3567.

Zoller, U. and Hushan, M. (2000) The Nonionic Surfactant Pollution Profile of Israel's Mediterranean Sea Coastal Water. Water Sci. and Tech., 42, 429- 435. 